\title{
Terpene Research Is Providing New Inspiration for Scientists
}

\author{
Pavel B. Drasar ${ }^{1, *(D)}$ and Vladimir A. Khripach ${ }^{2}$ (D) \\ 1 Department of Chemistry of Natural Compounds, University of Chemistry and Technology, Technicka 5, \\ 16628 Prague, Czech Republic \\ 2 Institute of Bioorganic Chemistry, National Academy of Sciences of Belarus, 5/2 Academician V. F. Kuprevich \\ Street, BY-220141 Minsk, Belarus; khripach@iboch.by \\ * Correspondence: drasarp@vscht.cz
}

Citation: Drasar, P.B.; Khripach, V.A. Terpene Research Is Providing New Inspiration for Scientists. Molecules 2021, 26, 5480. https://doi.org/ $10.3390 /$ molecules 26185480

Received: 2 September 2021 Accepted: 8 September 2021 Published: 9 September 2021

Publisher's Note: MDPI stays neutral with regard to jurisdictional claims in published maps and institutional affiliations.
This current Special Issue of Molecules gathers selected communications on terpenes and terpene derivatives, clearly demonstrating the sustained interest in and importance of natural products in this field; fields connected to secondary metabolites; and renewable resources of plant and animal compounds for medicinal, material, supramolecular, and general chemistry research.

This issue gathers 17 papers, 5 review articles, and 12 research communications with a vast range of topics with different perspectives, such as the optimization of FRAP methodology for studies based on selected monoterpenes [1], and the improved functioning of fibroblasts and endothelial cells and accelerated healing of cutaneous wounds in mice caused by uvaol [2]. It presents a new iridoid and three new bis-iridoid glycosides from the leaves of Lasianthus verticillatus, lasianosides F-I [3], and atypical lindenane-type sesquiterpenes from Lindera myrrha [4]. It comprises a study of antibacterial and antifungal sesquiterpenoids from the aerial parts of Anvillea garcinii [5] and phytochemical and safety evaluations of volatile terpenoids from Zingiber cassumunar on mature carp peripheral blood mononuclear cells and embryonic zebrafish [6]. Similarly, it presents the cytotoxic and anti-inflammatory effects of ent-kaurane derivatives isolated from the alpine plant Sideritis hyssopifolia [7]. The issue also lists the prenyleudesmanes and a hexanorlanostane from the roots of Lonicera macranthoides [8]. There is discussion on the quantitative analysis of terpenic compounds in microsamples of resins by capillary liquid chromatography [9] and high-throughput ${ }^{1} \mathrm{H}$-NMR-based screening for the identification and quantification of heartwood diterpenic acids in four black pine Pinus nigra marginal provenances in Greece [10]. This Special Issue presents the naturally occurring pentacyclic triterpene betulin, which promotes differentiation of human osteoblasts in vitro and exerts an osteoinductive effect on the hFOB 1.19 cell line through activation of JNK, ERK1/2, and mTOR kinases [11]. Two new 11,20-epoxybriaranes are described from the gorgonian coral Junceella fragilis from Ellisellidae [12].

The review articles describe the issue of topical administration of terpenes encapsulated in nanostructured lipid-based systems [13]; an overview of the synthesis, modification, and biological activity of diosgenyl $\beta$-D-glycosaminosides [14]; metabolic engineering of Escherichia coli for the production of lycopene [15]; traps and pitfalls-unspecific reactions in metabolic engineering of sesquiterpenoid pathways [16]; and the recent achievements in medicinal and supramolecular chemistry of betulinic acid and its derivatives [17].

The Special Issue also aims to commemorate the great work and legacy of Prof. Kenji Mori, providing important material not only to many chemists but also to the specialists in several other fields.

Funding: This research received no external funding.

Acknowledgments: The Guest Editor wishes to thank all the authors for their contributions to this Special Issue, all the reviewers for their work in evaluating the submitted articles, and the editorial staff of Molecules for their kind assistance. 
Conflicts of Interest: The author declares no conflict of interest.

\section{References}

1. Wojtunik-Kulesza, K.A. Approach to Optimization of FRAP Methodology for Studies Based on Selected Monoterpenes. Molecules 2020, 25, 5267. [CrossRef] [PubMed]

2. Carmo, J.; Cavalcante-Araújo, P.; Silva, J.; Ferro, J.; Correia, A.C.; Lagente, V.; Barreto, E. Uvaol Improves the Functioning of Fibroblasts and Endothelial Cells and Accelerates the Healing of Cutaneous Wounds in Mice. Molecules 2020, 25, 4982. [CrossRef] [PubMed]

3. Al-Hamoud, G.A.; Orfali, R.S.; Takeda, Y.; Sugimoto, S.; Yamano, Y.; Al Musayeib, N.M.; Fantoukh, O.I.; Amina, M.; Otsuka, H.; Matsunami, K. Lasianosides F-I: A New Iridoid and Three New Bis-Iridoid Glycosides from the Leaves of Lasianthus verticillatus (Lour.) Merr. Molecules 2020, 25, 2798. [CrossRef] [PubMed]

4. $\quad$ Duong, T.-H.; Beniddir, M.A.; Trung, N.T.; Phan, C.-T.D.; Vo, V.G.; Nguyen, V.-K.; Le, Q.-L.; Nguyen, H.-D.; Pogam, P.L. Atypical Lindenane-Type Sesquiterpenes from Lindera myrrha. Molecules 2020, 25, 1830. [CrossRef] [PubMed]

5. Perveen, S.; Alqahtani, J.; Orfali, R.; Aati, H.Y.; Al-Taweel, A.M.; Ibrahim, T.A.; Khan, A.; Yusufoglu, H.S.; Abdel-Kader, M.S.; Taglialatela-Scafati, O. Antibacterial and Antifungal Sesquiterpenoids from Aerial Parts of Anvillea garcinia. Molecules 2020, 25, 1730. [CrossRef] [PubMed]

6. Mektrirat, R.; Yano, T.; Okonogi, S.; Katip, W.; Pikulkaew, S. Phytochemical and Safety Evaluations of Volatile Terpenoids from Zingiber cassumunar Roxb. on Mature Carp Peripheral Blood Mononuclear Cells and Embryonic Zebrafish. Molecules 2020, 25, 613. [CrossRef] [PubMed]

7. Aimond, A.; Calabro, K.; Audoin, C.; Olivier, E.; Dutot, M.; Buron, P.; Rat, P.; Laprévote, O.; Prado, S.; Roulland, E.; et al. Cytotoxic and Anti-Inflammatory Effects of Ent-Kaurane Derivatives Isolated from the Alpine Plant Sideritis hyssopifolia. Molecules 2020, 25, 589. [CrossRef] [PubMed]

8. Lyu, H.; Liu, W.; Bai, B.; Shan, Y.; Paetz, C.; Feng, X.; Chen, Y. Prenyleudesmanes and A Hexanorlanostane from the Roots of Lonicera macranthoides. Molecules 2019, 24, 4276. [CrossRef] [PubMed]

9. Ponce-Rodríguez, H.D.; Herráez-Hernández, R.; Verdú-Andrés, J.; Campíns-Falcó, P. Quantitative Analysis of Terpenic Compounds in Microsamples of Resins by Capillary Liquid Chromatography. Molecules 2019, 24, 4068. [CrossRef] [PubMed]

10. Ioannidis, K.; Melliou, E.; Magiatis, P. High-Throughput 1H-Nuclear Magnetic Resonance-Based Screening for the Identification and Quantification of Heartwood Diterpenic Acids in Four Black Pine (Pinus nigra Arn.) Marginal Provenances in Greece. Molecules 2019, 24, 3603. [CrossRef] [PubMed]

11. Mizerska-Kowalska, M.; Sławińska-Brych, A.; Kaławaj, K.; Żurek, A.; Pawińska, B.; Rzeski, W.; Zdzisińska, B. Betulin Promotes Differentiation of Human Osteoblasts In Vitro and Exerts an Osteoinductive Effect on the hFOB 1.19 Cell Line Through Activation of JNK, ERK1/2, and mTOR Kinases. Molecules 2019, 24, 2637. [CrossRef] [PubMed]

12. Lin, C.-C.; Su, J.-H.; Chen, W.-F.; Wen, Z.-H.; Peng, B.-R.; Huang, L.-C.; Hwang, T.-L.; Sung, P.-J. New 11,20-Epoxybriaranes from the Gorgonian Coral Junceella fragilis (Ellisellidae). Molecules 2019, 24, 2487. [CrossRef]

13. Lasoń, E. Topical Administration of Terpenes Encapsulated in Nanostructured Lipid-Based Systems. Molecules 2020, 25, 5758. [CrossRef]

14. Grzywacz, D.; Liberek, B.; Myszka, H. Synthesis, Modification and Biological Activity of Diosgenyl $\beta$-d-Glycosaminosides: An Overview. Molecules 2020, 25, 5433. [CrossRef]

15. Wang, Z.; Sun, J.X.; Yang, Q.; Yang, J. Metabolic Engineering Escherichia coli for the Production of Lycopene. Molecules 2020, 25, 3136. [CrossRef] [PubMed]

16. Frey, M. Traps and Pitfalls-Unspecific Reactions in Metabolic Engineering of Sesquiterpenoid Pathways. Molecules 2020, 25, 1935. [CrossRef] [PubMed]

17. Bildziukevich, U.; Özdemir, Z.; Wimmer, Z. Recent Achievements in Medicinal and Supramolecular Chemistry of Betulinic Acid and Its Derivatives. Molecules 2019, 24, 3546. [CrossRef] [PubMed] 